\title{
THE EFFECTS OF SHORT-TERM AND LONG-TERM ORIENTED MANAGERIAL BEHAVIOR ON MEDIUM-TERM FINANCIAL PERFORMANCE: LONGITUDINAL EVIDENCE FROM EUROPE
}

\author{
Matthias F. Brauer \\ Institute of Management, University of St. Gallen, Dufourstrasse 40a, \\ 9000 St. Gallen, Switzerland \\ E-mail:matthias.brauer@unisg.ch \\ Received 04 April 2012; accepted 14 June 2012
}

\begin{abstract}
Short-term orientation aimed at maximizing quarterly results at the expense of long-term corporate performance and survival has become severely criticized. In the face of continuously decreasing chief executive officer (CEO) tenure, CEOs, however, seem to have few incentives to embrace long-term oriented behaviour. Instead, the question of foremost importance to self-interested CEOs is whether short-term orientation already harms financial performance in the three to four years of their own tenure, and whether CEOs stand a chance of benefiting from long-term orientation while still in office. CEOs thus face an intriguing ethical dilemma between optimizing their financial pay-off within their own tenure and securing the longer-term well-being of the corporation, its employees, and other major stakeholders. Consequently, our longitudinal study focuses on the medium-term performance implications of short-term and long-term orientation in Europe's largest publicly listed companies. Results indicate that short-term orientation negatively impacts on medium term performance while long-term oriented behavior is positively associated with corporate performance in the medium term. Our findings advance managerial myopia theory, and provide insights into one of the most central ethical dilemmas faced by corporate executives today.
\end{abstract}

Keywords: short-termism, managerial myopia, managerial self-interest.

Reference to this paper should be made as follows: Brauer, M. F. 2013. The effects of short-term and long-term oriented managerial behavior on medium-term financial performance: longitudinal evidence from Europe, Journal of Business Economics and Management 14(2): 386-402.

JEL Classification: M21, M50, G32, L22.

\section{Introduction}

"The new continental European banking culture should value long-term thinking instead of short-termism and financial alchemy" (Horst Köhler, former German Federal President, 2008).

In the face of the global financial (subprime) crisis which is reasoned to be brought about largely by excessive short-term thinking, societal expectations towards corporate 
executives to live up to their stewardship roles and long-term responsibilities have increased dramatically. As a consequence, the issue of how to curb short-term orientation has risen not only to the top of political agendas worldwide but has also become most prominent in the scientific and practical discourse in the area of corporate governance (e.g., Dallas 2012).

Even before the financial crisis, several initiatives have been launched dedicated to reasserting long-term orientation in business decision-making and investing. For instance, in the U.S., a number of prominent firms, including Pfizer Inc, PepsiCo, and Xerox Corporation, agreed to subscribe to a set of guiding principles (Aspen Principles) meant to enforce greater long-term orientation in their corporate activities. These and other initiatives are largely driven by the concern about an excessive short-term orientation of corporate executives of publicly listed companies. Short-term orientation - or often termed short-termism - is defined as the excessive focus of corporate executives, investors, and analysts on short-term quarterly earnings at the expense of long-term corporate strategy, performance, and sustainability (Porter 1992; Sappideen 2011; Stein 1988).

But despite these initiatives and the evidently harmful effects of short-term orientation on long-term firm performance and survival, more than $75 \%$ of chief financial officers (CFOs) acknowledge choosing investments with lower net present value (NPV) due to a shorter payoff horizon (Graham et al. 2005). Today, top management teams (TMT) face a major dilemma in respect to long-term oriented behavior. Recent management surveys have shown that average tenure of CEOs in major publicly listed Western European corporations is approximately four years (Lucier et al. 2006). This number is expected to decrease further over the next few years - not least due to a lack of trust and growing impatience of shareholders with corporate executives. In today's business environment, CEOs thus seem to have few incentives to take long-term oriented measures as CEOs are very unlikely to actually reap the benefits of long-term oriented measures given their continuously shorter tenure.

Conversely, against the backdrop of shorter CEO tenure, short-term oriented behavior seems to be associated with higher gains for CEOs. However, what has often been left ill-considered is that this only holds true if these short-term measures do not 'backfire' within the CEO's own tenure in the particular firm. For instance, managerial opportunism theory has argued that short-term behavior might be an optimal choice from a manager's perspective. Using moral hazard models, it has been shown that managers prefer shortterm investments that pay off quickly to enhance personal reputation (Campbell, Marino 1994; Narayanan 1985), or that managers are preoccupied with job safety and therefore favour short-term relative to long-term payoffs (Hirshleifer, Thakor 1992). These views, however, do not consider any negative backlash effects of such short-term behavior within the CEO's approximately three to four year long tenure in the particular firm.

In essence, CEOs of large publicly listed firms today are not so much concerned about either the short-term or the long-term. Instead, CEOs are most of all interested in maximizing financial returns over their expected three to four year tenure period. What is of primary interest to them are thus the medium-term performance implications of short-term and long-term oriented behavior. This strong interest in the medium-term performance implications has been spurred by the fact that many compensation and 
bonus schemes nowadays have a build-in holding period for shares or options of usually three to four years.

So far, however, the medium-term performance implications of short-term and longterm oriented managerial behavior have remained unexplored. The current paper aims to fill this gap. In contrast to previous research which relied on a single indicator (i.e, R\&D expenses) to measure long-term orientation (e.g., Bushee 1998; David et al. 2001; Graves 1988; Hansen, Hill 1991; Zahra 1996), we devise - based on family firm research - a broader set of indicators for short-term and long-term orientation in three key organizational dimensions - human resource development, business portfolio development and corporate investment behavior. We then empirically explore the impact of short-term and long-term oriented behavior in these three key organizational dimensions on medium-term financial performance. Across all three organizational dimensions, we find that short-term oriented behavior is found to be negatively associated with mediumterm financial performance while long-term oriented behavior is positively associated with medium-term financial performance. Our findings thus inform managerial myopia theory (Stein 1988) which has spurred a controversial discourse on the influence of short-run managerial actions on firm performance in the areas of management science and financial and business economics. The existing paradigm of managerial myopia theory is extended by indicating that short-term orientation already starts negatively impacting firm performance in the medium-term. Importantly, our results suggest that the widely held assumption that short-term orientation is generally aligned with managerial self-interest while long-term orientation stands in stark contradiction to managerial self-interest seems too simplistic; especially so, if we consider the prevalent nature of today's compensation and bonus schemes with three to four year holding periods for stock and option payments.

\section{Extant research on short-term and long-term orientation}

In strategic management research, previous studies have almost exclusively focused on the antecedents of short-term oriented managerial behavior. Flawed management practices (e.g., Hayes, Abernathy 1980; Miller 2002), stock-market myopia (Laverty 1996; Stein 1989) and managerial self-interest (Campbell, Marino 1994; Narayanan 1985) are the most commonly named reasons for short-term oriented managerial behavior. In a recent and fine-grained study of individual, group, firm-level and environmental factors affecting managerial short-term orientation, Marginson and Mcaulay (2008) find evidence that short-term orientation also has a strong social dimension. Specifically, short-term orientation is found to be positively associated with managers' individual experience of role ambiguity. Additionally, the study finds evidence that individual manager's short-term orientation is positively associated with other group member's short-term orientation.

In finance and economics, the debate has centered less on the sources of short-term orientation but on the basic question whether stock-markets (i.e. investors, analysts) are short-term oriented at all or not. Studies in this area have focused on the reactions 
by the stock-market in response to firms' R\&D investment decisions (Chan et al. 1990; Jacobson, Aaker 1993; Jarrell et al. 1985; Woolridge, Snow 1990). Most of these studies come to the result that firms' market values are positively related to R\&D outlays. Woolridge (1988) and Chan et al. (1990) find that even announcements of increases in $\mathrm{R} \& \mathrm{D}$ investments are associated with market value increases. This has been taken as evidence that stock-markets are not myopic.

Common to both streams of inquiry in strategic management as well as in economics and finance research (except for the studies by Laverty 1996 and Marginson, Mcaulay 2008 ) is the primary reliance on research and development (R\&D) expenses as a single indicator for firms' long-term orientation. For several reasons, however, we believe that this indicator is likely to be an inappropriate and imprecise measure of long-term orientation. First, the assumption that R\&D spending is generally long-term is highly questionable. Earlier, Laverty (1993) convincingly disputed this assumption and showed that R\&D data included many short-term projects. Second, R\&D spending is an unsuitable proxy to capture long-term orientation in service firms since these firms simply do not list such a position in their profit and loss statements. Third, by using R\&D spending, studies - if at all - only capture long-term orientation in corporate investment behavior. Other important organizational dimensions are left unconsidered. For instance, changes to the human resource profile of a firm as well changes to a firm's business portfolio seem important organizational dimensions in which short-term or long-term orientation are likely to generate very different results. Past research thus advocated the development of new measures for short-term and long-term orientation along several organizational dimensions (Laverty 1996; Marginson, Mcaulay 2008).

Overall, it becomes apparent that previous research has been exclusively concerned with the antecedents of long-term and short-term orientation. In contrast, relatively little research attention has been directed towards the optimality of these orientations in the medium-term. This, however, seems most critical given CEOs average tenure of approximately three to four years and given compensation and bonus schemes which also focus TMTs' attention on the medium-term. Moreover, previous management research has relied on a single indicator for long-term and short-term orientation - the overall level of R\&D spending respectively the change in $R \& D$ spending from one year to the other. This measure, however, seems somehow imprecise and its application limited necessitating the development of new proxies for firms' extent of short-term and longterm orientation.

\section{Alternative secondary measures for short-term and long-term orientation and hypotheses}

In earlier research, the neglect of alternative secondary measures of short-term and longterm orientation has been lamented as the most far-reaching challenge to advance the current debate on short-termism (Laverty 1996: 851; Marginson, Mcaulay 2008) ${ }^{1}$. For

\footnotetext{
${ }^{1}$ The need to devise new measures of long-term orientation has been recognized also in marketing research (i.e., Bearden et al. 2006).
} 
deriving suitable secondary proxies of long-term respectively short-term orientation, we relied on family firm literature and specifically an analysis of the primary characteristics of family firms which are put forward in this literature. This approach was grounded in the fact that greater long-term orientation is often considered a competitive advantage of family firms relative to non-family firms. In fact, performance differences between family firms and public firms have been argued to primarily result from the fact that "families potentially have longer horizons than other shareholders, suggesting a willingness to invest in long-term projects relative to shorter managerial horizons" (Anderson, Reeb 2003: 1305; James 1999; Le Breton-Miller, Miller 2006; Miller, Breton-Miller 2005).

Based on family firm research, family firms seem to differ from non-family firms along three major organizational dimensions: human resource development, business portfolio management and investment behavior.

Human Resource Management. A major hallmark of family firms is that they have been found to avoid major fluctuations both in their overall workforce as well as their senior management ranks in comparison to non-family firms (Guzzo, Abbott 1990; Miller, Le Breton-Miller 2003). Long-term oriented family firms are thought to weather temporary market downturns without resorting to major downsizing. Reason is that the knowledge and experience of senior managers and the workforce are seen as valuable assets which are costly to replace or to rebuild. In line with this notion, Mr Wendelin Wiedeking, former CEO of the family owned German sports car manufacturer Porsche AG, which is known for its long-term orientation once said: "Long-term orientation and long-term employability go hand in hand". In contrast, short-term oriented firms are likely to react very sensitive to unfavourable temporary market conditions or below expected quarterly or annual returns. Research on corporate downsizing has shown that stock-markets react positive to downsizing announcements (e.g., Chalos, Chen 2002). Downsizing is thus a proven method to increase short-term performance while its long-term effects are highly questionable due to a loss of trust and commitment in the organization.

The fact that enduringness of a relationship is a key component of a firm's long-term orientation can also be deduced from research on buyer-supplier relationships (Lee, Dawes 2005; Ryu et al. 2007). In this research, long-term orientation has among other items been measured by the willingness to make sacrifices to help the seller from time to time and the expected length of time the buyer and the seller will work together.

The notion that long-term orientation goes hand in hand with a stable development of the workforce is further supported by the British Trade Union Congress (TCU) report published in 2006 on "investment chains: addressing corporate and investor short-termism". The TUC report (2006) argues that long-term orientation comprises the retention of and investment in employees on a long-term basis, rather than look for quick fixes to meet the demands of investors. Together, these aspects underscore that variability in the workforce may seem a valid proxy for short-term orientation.

Since extant theory does not provide any predictions on the optimality of short-term orientation in human resource management for the medium-term, we offer two competing hypotheses: 
H1a: Greater variability in the number of employees is positively related to mediumterm firm profitability.

H1b: Greater variability in the number of employees is negatively related to mediumterm firm profitability.

As mentioned above, family firm research suggests that family-owned firms are also characterized by greater stability in their senior management ranks when compared with non-family firms. This stability in senior management ranks is said to correlate with longer time horizons and longer-term investment in focal capabilities (Le BretonMiller, Miller 2006). In contrast, short-term oriented firms are much more likely to quickly replace top managers in case certain performance hurdle rates have not been met. Consequently, short-term oriented firms are likely to be characterized by greater variability in top management team (TMT) size. Similar to downsizing of the workforce, the replacement of top level managers in low performing firms has been shown to lead to increases in market valuation in the short-term. This effect is explained by the higher likelihood of the new top management to take severe measures (i.e., divestiture of low-performing units).

Again, due to the absence of sound theoretical predictions and the absence of previous empirical findings regarding the medium-term performance effects of short-term oriented human resource management, we hypothesize:

H2a: Variability in TMT size is positively associated with medium-term firm profitability.

H2b: Variability in TMT size is negatively associated with medium-term firm profitability.

Business Portfolio Management. Another indication for family firms' long-term orientation has been their willingness to sustain a business in times of trouble (Le BretonMiller, Miller 2006). Family firms are thus commonly perceived to pursue a continuous and more balanced portfolio development strategy compared to non-family firms. Primarily, this implies that long-term oriented firms disdain from excessive acquisition activity. Instead, long-term oriented firms show a fairly even level of acquisition activity over time. In contrast, short-term oriented firms are likely to act much more opportunistically in their acquisition behavior and thus show much greater variability in their acquisition behavior. For instance, short-term oriented firms are likely to embark on major acquisition sprees if they perceive that the market is generally undervaluing targets though this may cause indigestion problems for the firm in later periods. Consequently, as part of long-term orientation, the TUC report (2006) demands a "cool-headed, balanced approach to mergers and acquisitions". Overall, we thus hypothesize:

H3a: Variability in a firm's acquisition behavior is positively associated with mediumterm performance.

H3b: Variability in a firm's acquisition behavior is negatively associated with mediumterm performance. 
Corporate Investment Behavior. As mentioned above, firms' investment behavior has been used as the most common proxy for firm short-term and long-term orientation. Given the disadvantages of R\&D expenses as a proxy for long-term orientation, we suggest an alternative measure which is also based on insights from family research. In family firm research, it is argued that family CEOs are not haunted by quarterly results and are more willing to inject profits back into the business on a stable and continuous basis (e.g., Kets de Vries 1993). Similarly Le Breton-Miller and Miller (2006) argue that a hallmark of long-term oriented family firms is that they invest deeply and continuously in the competencies and facilities required to attain the core mission of the firm. In contrast, short-term oriented investors and firms are more likely to favour that free cash flows are distributed to shareholders in form of dividends leading to increased attractiveness of the firm's stock in the short-term. Consequently, we regard capital expenditures into operations as a suitable proxy for long-term orientation in firms' investment behavior.

H4a: Capital expenditures into operations are positively associated with medium-term performance.

H4b: Capital expenditures into operations are negatively associated with medium-term performance.

\section{Methods}

To test the medium-term performance implications of short-term and long-term oriented behavior in these three organizational dimensions, we compiled a panel data set of firms that were listed on either the Dow Jones Eurostoxx 50 or Dow Jones Stoxx 50 in 1996 and on which relevant data were available. In total, our panel thus contains 73 firms which we tracked for a period of eleven years (1996-2006). We focus on a sample of European firms since empirical evidence on the subject matter has been scarce for European countries with previous empirical research on managerial myopia exclusively focused on the US. Moreover, research in cross-cultural management has argued that material differences in time orientation exist between US and European firms which makes a focus on European firms interesting to explore potential differences (Hofstede, G., Hofstede, J. G. 2003). Additionally, our focus on European firms seems methodically more robust than a "mixed" sample given differences in accounting standards across US and European firms. 1996 was chosen as the starting point for our empirical analysis since shareholder activism and the issue of short-term orientation became a prominent topic in public debate in the mid-90s. Moreover, data coverage on European publicly listed firms is poor prior to 1996. Further, the time period from 1996 to 2006 covers both economic downturns as well as upturns so that our findings are unlikely to be distorted by one-sided cyclical economic effects. 2006 seemed an appropriate cut-off point for our data analysis to avoid confounding effects from the subprime crisis which started in 2007. Both the Dow Jones Eurostoxx 50 and the Dow Jones Stoxx 50 include a wide variety of industries, thereby reducing as much as possible potential industry and survival biases. Organizational and financial data were collected from Thomson 
OneBanker. Data on the firms' acquisition activity during the eight year period was extracted from the Securities Data Company (SDC) Platinum database provided by Thomson Financial.

Dependent Variable. Our dependent variable is return on assets (ROA). To capture the medium-term performance effects of short-term and long-term orientation, we work with a three year industry-adjusted average. A three year time window also corresponds with prior conceptualizations of short-term and long-term performance (e.g., Le BretonMiller, Miller 2006; Papadakis 1998). For instance, Papadakis (1998) uses 2-year averages to determine short-term performance and five year averages to determine long-term performance. Also, given CEOs' average tenure of approximately 4 years and expectations that tenure is going to decrease further (Le Breton-Miller, Miller 2006; Lucier et al. 2006), a three year performance average seemed appropriate to assess mediumterm performance.

Independent Variables. As mentioned earlier, we use two indicators to assess shortterm orientation in human resource management. First, variability in the workforce was measured as the relative year-to-year change in a firm's number of employees. Second, variability in TMT size was measured as the relative year-to-year change in the number of TMT members.

To assess short-term orientation in business portfolio management, we use the variability in acquisition activity. Short-term orientated firms have been argued to act opportunistically and thus show great variance in their level of organizational activity, while long-term oriented firms are generally assumed to pursue a steady portfolio development. We measured the variability in acquisition activity as the relative year-to-year change in the total number of acquisitions conducted by the firms.

To assess the degree of long-term orientation in firm investment behavior, we used the capital expenditure to assets ratio (Capex ratio). This ratio is commonly used to assess the extent to which firms invest in preserving and enhancing their existing asset base. It is assumed that long-term oriented firms continuously invest in their asset base while short-term oriented firms are more likely to use funds to satisfy investors' needs, for instance, through higher dividend payouts. The Capex ratio was operationalized as the firms' capital expenditures divided by firms' total assets.

Control Variables. For our analyses, we used a standard set of controls. Firm diversification was included as a control because it has also been shown to potentially influence firm performance. Following the convention of prior research (Bergh 1995; Hoskisson, Johnson 1992), we measured firm diversification using the concentration ratio which was measured as the sales of the largest business relative to the firm's total sales. Next, we controlled for firm size. In keeping with prior research (e.g., Sanders 2001), we measured firm size as the natural logarithm of firm total sales. Since CEO tenure has been found to influence board vigilance (e.g., Hill, Phan 1991), we control for CEO tenure which is defined as the number of years a CEO has been in office. Further, to control for previous firm performance we incorporated firms' previous return on assets (ROA) in our set of controls (Walters et al. 2007). Additionally, we used the debt-to-equity ratio 
and current ratio (current assets/current liabilities) as controls for the financial structure of the firm. In keeping with prior research, we used a year trend variable to account for differences across time (Deutsch et al. 2007). All independent variables and controls were lagged by one period ${ }^{2}$.

To explore the medium-term performance implications of short-term and long-term oriented managerial behavior, we estimated fixed effects cross-sectional time series regressions. Fixed effects OLS corrects for autocorrelation of disturbances due to time invariant firm-specific effects by inserting an error term that is assumed to be constant over time (Kennedy 1998). We chose the more conservative fixed effect model over a random effects model since the results of a Hausman test (Greene 2008; Hausman et al. 1984) rejected the randomness of residuals hypothesis. As part of our robustness analysis, however, we also compared results to the random-effects model and found that results remained qualitatively identical in the fixed and random-effects models. In fact, coefficients were estimated more precisely in the latter. This lends additional confidence to our conclusions (Wooldridge 2001).

\section{Results}

The descriptive statistics and correlations are shown in Table 1. We find that the predictor variables are not strongly correlated among themselves or with any of the control variables. Thus, multicollinearity does not seem to be an issue in our data.

Validity Analyses. Before testing our initial Hypotheses (1a-4b), we conducted several analyses to test for the validity of our indicators for short-term and long-term orientation. These analyses seemed necessary as our indicators had been derived by research on family firms but have not been confirmed as suitable indicators for firms' short-term and long-term orientation in previous empirical research efforts. For this purpose, we tested the short-term performance effects of our indicators. In order to do so, we used multiple short-term outcome measures as dependent variables - namely one-year ROA, earnings before taxes (EBIT), and market value (MV). The variability in number of employees was found to have a strong positive effect on short-term market performance $(p<0.05)$. This is in line with previous studies showing positive stock-market effects (so-called cumulative abnormal returns) for downsizing measures. The variability in TMT size was associated with strong positive effects in both short-term ROA $(p<0.05)$ and EBIT $(p<0.1)$. The variability in acquisition behavior was found to be the strongest indicator for short-term orientation. For all three short-term performance measures, we found a strong, positive relationship with variability in acquisitions $(p<0.05)$. For the capital expenditures to assets ratio - our single indicator for long-term orientation - we found that it is negatively associated with short-term EBIT $(p<0.1)$. Overall, the validity of our measures can thus be judged satisfactory.

\footnotetext{
${ }^{2}$ It would have been desirable to also include corporate executives' compensation structure as controls. However, this data is not available for European firms during this period. Even today, in many European jurisdictions companies are still not obliged to publicly report corporate executive compensation.
} 


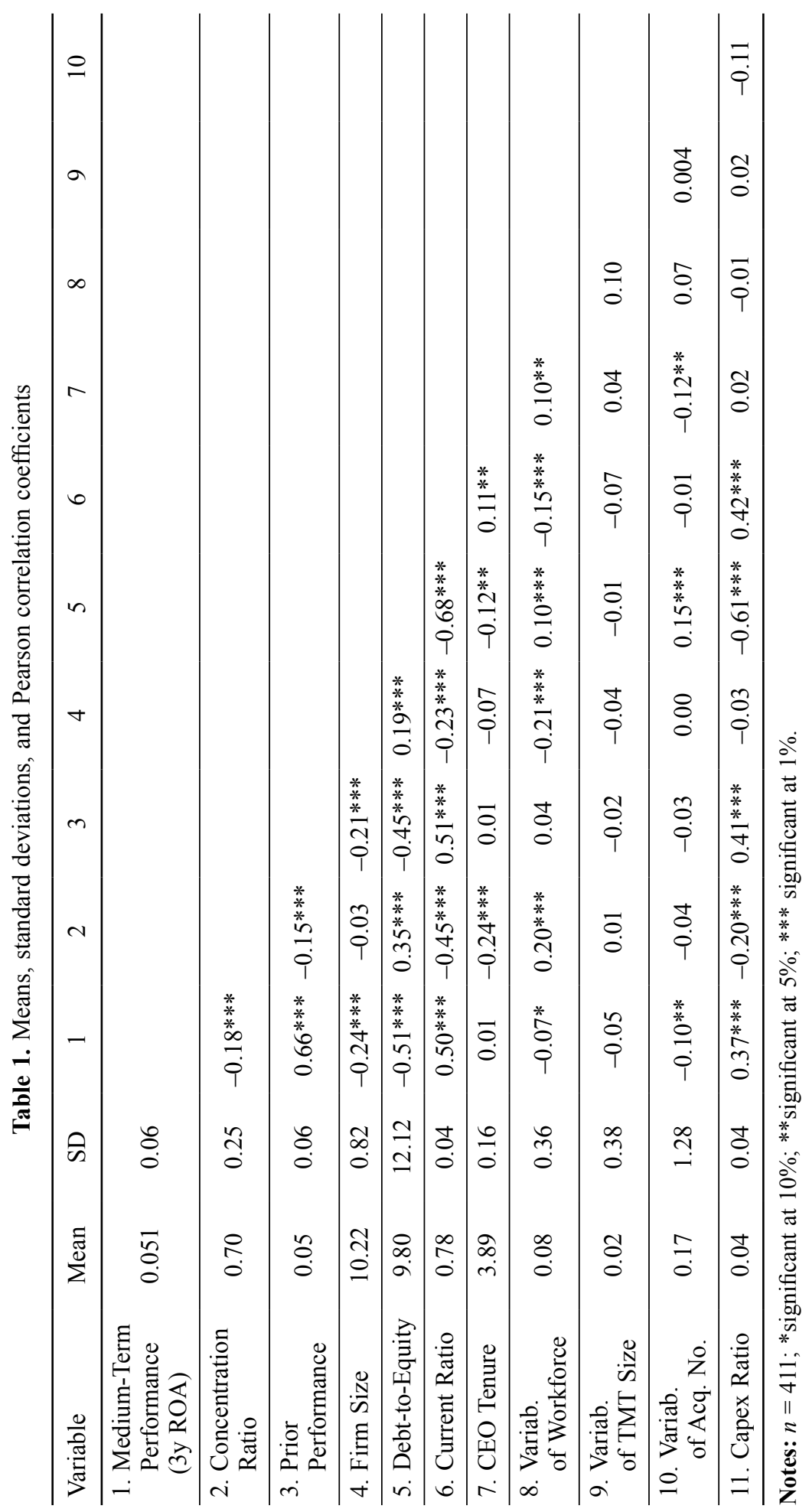


Hypothesis Testing. The OLS fixed effects regression estimates for our analyses on the medium-term performance effects of short-term and long-term orientation in human resource management, business portfolio management and corporate investment behavior are presented in Table 2. For all models, we used robust standard errors. Using the robust command in Stata has the advantage of taking heteroscedasticity into account while coefficient estimates are exactly the same as in straightforward OLS regression.

Table 2. Predictor variables regressed on medium-term financial performance (3-year ROA)

\begin{tabular}{|c|c|c|c|c|c|}
\hline \multirow{2}{*}{ Variable } & \multicolumn{5}{|c|}{ ROA (3-year average) } \\
\hline & Model I & Model II & Model III & Model IV & Model V \\
\hline \multirow{2}{*}{ Variability of Workforce } & & -0.01 & & & \\
\hline & & $(0.004)^{*}$ & & & \\
\hline \multirow{2}{*}{ Variability of TMT Size } & & & -0.01 & & \\
\hline & & & $(0.002)^{* *}$ & & \\
\hline \multirow{2}{*}{ Variability of Acq. No. } & & & & -0.003 & \\
\hline & & & & $(0.001)^{* * *}$ & \\
\hline \multirow{2}{*}{ Capex Ratio } & & & & & 0.14 \\
\hline & & & & & $(0.08)^{* *}$ \\
\hline \multirow{2}{*}{ Concentration Ratio } & 0.01 & 0.01 & 0.01 & 0.01 & 0.01 \\
\hline & $(0.01)$ & $(0.01)$ & $(0.01)$ & $(0.01)$ & $(0.01)$ \\
\hline \multirow{2}{*}{ Prior Performance } & -0.24 & -0.24 & -0.28 & -0.27 & -0.27 \\
\hline & $(0.08) * * *$ & $(0.07)^{* * *}$ & $(0.06)^{* * *}$ & $(0.07)^{* * *}$ & $(0.07) * * *$ \\
\hline \multirow{2}{*}{ Firm Size } & -0.02 & -0.02 & -0.02 & -0.02 & -0.02 \\
\hline & $(0.01)$ & $(0.01)^{*}$ & $(0.01)^{*}$ & $(0.01)^{* *}$ & $(0.01)$ \\
\hline \multirow{2}{*}{ Debt-to-Equity } & 0.00 & 0.00 & 0.00 & 0.00 & 0.00 \\
\hline & $(0.00)$ & $(0.00)$ & $(0.00)$ & $(0.00)$ & $(0.00)$ \\
\hline \multirow{2}{*}{ Current Ratio } & -0.00 & -0.00 & -0.00 & 0.01 & -0.00 \\
\hline & $(0.01)$ & $(0.01)$ & $(0.01)$ & $(0.01)^{*}$ & $(0.01)$ \\
\hline \multirow{2}{*}{ CEO Tenure } & -0.00 & -0.00 & -0.00 & -0.00 & -0.00 \\
\hline & $(0.001)$ & $(0.001)$ & $(0.001)$ & $(0.001)$ & $(0.001)$ \\
\hline \multirow{2}{*}{ Year } & 0.004 & 0.004 & 0.003 & 0.003 & 0.004 \\
\hline & $(0.001)^{* *}$ & $(0.001)^{* *}$ & $(0.001)^{* *}$ & $(0.001)^{* *}$ & $(0.001)^{* *}$ \\
\hline \multirow{2}{*}{ Constant } & -7.99 & -7.99 & -6.18 & -6.06 & -7.91 \\
\hline & $(3.08)^{* *}$ & $(3.08)^{* *}$ & $(2.20)^{* *}$ & $(2.49)^{* *}$ & $(2.86)^{* *}$ \\
\hline R-square & 0.26 & 0.27 & 0.34 & 0.37 & 0.27 \\
\hline F-value & $7.38^{* * *}$ & $6.83^{* * *}$ & $9.76^{* * *}$ & $6.89^{* * *}$ & $6.45^{* * *}$ \\
\hline
\end{tabular}

Notes: $n=411$; Robust t-statistics in parentheses; *significant at $10 \%$; **ignificant at $5 \%$; ***significant at $1 \%$. 
All models are highly significant $(p<0.01)$, and have considerable explanatory power. Model 1 in Table 2 represents our base model with just the controls. Results on the control variables emphasize the influence of prior performance on firms' medium-term performance. Prior firm performance is strongly negatively related to firms' mediumterm performance $(p<0.01)$.

Models II and III display the results for short-term orientation in human resource management. As shown in Model II, we find that short-term orientation proxied by the variability in the number of employees is negatively related to medium-term firm performance $(p<0.1)$. Model III also lends evidence for a negative impact of short-term oriented human resource management on medium-term performance. The variability in TMT size is negatively related to medium-term firm performance $(p<0.05)$. Hypotheses $1 b$ and $2 b$ are thus supported.

Model IV shows the impact of short-term oriented business portfolio management on medium-term financial performance. In line with Hypothesis 3b, the variability in firm acquisition behavior is strongly negatively associated with medium-term financial performance $(p<0.01)$. This result chimes in with research on organizational growth. Previous research has shown that firms with stable growth patterns (in terms of firm sales) outperform those firms which show a high degree of volatility in their growth patterns (Brauer, Laamanen 2008; Laamanen, Keil 2008).

Model V highlights the effect of long-term oriented corporate investment behavior on medium-term financial performance. In correspondence with the results above and with Hypothesis $4 \mathrm{a}$, we find that long-term oriented investment behavior is positively associated with medium-term financial performance. Specifically, Capex ratio is positively related to medium-term financial performance $(p<0.05)$.

Robustness tests. We further conducted some post-hoc empirical analyses to test for the robustness of our empirical results. Specifically, we re-ran our analyses utilizing the firms' medium-term stock-market performance measured as the three year market value adjusted by dividend payments as dependent variable. When comparing the results across the two types of analyses, we find consistent results for the effects of variability in TMT size $(p<0.1)$, variability in acquisition behaviour $(p<0.01)$, and Capex ratio $(p<0.1)$ on medium-term accounting and stock-market performance. Only the relationship between variability in workforce and medium-term stock-market performance is found to be non-significant. In sum, we thus find that the relationships between our predictor variables and medium-term stock-market performance remain widely consistent but are statistically weaker when compared with their influence on the firms' mediumterm accounting performance. The weaker statistical relationships are explained by the fact that in general a firm's stock-market performance is influenced by a much greater host of factors than a firm's accounting performance, and that the predictor variables are more closely tied to a firm's accounting performance than to a firm's stock-market performance. 


\section{Discussion and implications for theory and practice}

In public debate, the global financial ('subprime') crisis has frequently been argued to have resulted mainly from 'subprime', short-term oriented leadership by corporate executives including skewed incentive structures for mortgage dealers and traders that favour the short term over the long term. Consequently, the issue of curbing short-term orientation has come to the forefront of discussions in corporate governance research and practice. Our study thus directly relates to this current and ongoing debate in corporate governance research and practice (e.g., Dallas 2012; Sappideen 2011).

Our study extends research on short-term and long-term orientation by developing a new set of (secondary data) indicators to assess firms' degree of short-term and longterm orientation. Drawing on family firm research, we derive four indicators in firms' human resource management (i.e., variability in the workforce, variability in TMT size), portfolio management (i.e., variability in acquisition behavior) and investment behavior (i.e., capex ratio). Preliminary analyses suggest that these indicators show satisfactory validity as measures for firms' short-term and long-term orientation. The study is thus responsive to prior research that criticized extant proxies for long-term orientation (i.e., R\&D spending) and advocated the development of new measures along several organizational dimensions (Laverty 1996; Marginson, Mcaulay 2008).

Most importantly, we focus on a "sweet spot" in the theoretical discussion on shortterm and long-term orientation by assessing their medium-term financial impact. The concept of intertemporal choice simply suggests that short-term oriented behavior is suboptimal behavior focusing on the short-term to the detriment of the long-term. It has remained unclear at which point in time short-term orientation will start to produce weaker results than long-term orientation. Our results suggest that, at least, for the key organizational dimensions considered in our study, short-term orientation already starts to lose out to long-term orientation in the medium-term (3-years). Our results thus reorient the discussion on managerial myopia. The widely held assumption that short-term orientation is generally aligned with managerial self-interest while long-term orientation stands in stark contradiction to managerial self-interest seems too simplistic; especially so if we consider CEO's average tenure and the fact that modern compensation and bonus schemes have build-in holding periods of three to four years for TMTs' stock and option payments. Importantly, our empirical findings are in line with some of the most recent studies in accounting research using the extent of firms' real earnings management and quarterly earnings guidance as a proxy for managerial short-termism (e.g., Cheng et al. 2007; Zhao et al. 2012) . $^{3}$ Based on a sample of US firms, Zhao et al. (2012), for example, find that abnormal real earnings management is generally associated with lower industry-adjusted cash flows from operating activities in the subsequent three years. Cheng et al. (2007), who also draw upon a US sample, find support for

\footnotetext{
${ }^{3}$ According to Ewert and Wagenhofer (2005: 1102), real earnings management is defined as adjusting the timing, magnitude and/or structure of real business transactions with an intent to alter reported earnings in order to meet analyst forecasts. The definition implies that such changes are costly to the firm in the medium to long-term.
} 
the fact that firms which give quarterly earnings guidance experience adverse effects on earnings growth in subsequent years (2003-2005). Conversely, however, Taylor and $\mathrm{Xu}$ (2010) who use matched-sample analysis to investigate the consequences of real earnings management activities on firms' subsequent operating performance find that firms identified as manipulating operations to manage earnings do not experience a significant decline in their subsequent operating performances (i.e., ROA, operating cash flow, size adjusted returns). Some of the equivocality in past research on the effects of real earnings management on medium-term performance may stem from the fact that real activities manipulation has been proxied by abnormal levels of production costs, discretionary expenditures, and cash flow from operations. The proxies introduced in the current study may serve as a viable alternative to detect real earnings management, and thus complement the existing stream of research on managerial myopia in accounting research.

Practical Implications. We believe that both our analytical approach to assessing short-term and long-term orientation as well as our empirical results provide actionable knowledge to corporate managers and boards of directors. The set of indicators we devised for assessing short-term and long-term orientation can be readily used by both managers and boards as metrics for determining their firm's degree of short-term and long-term orientation. Our set of indicators can then also be used to benchmark the firm's degree of short-term and long-term orientation in comparison to industry peers. To some extent, this may help boards to intervene in due time if these indicators suggest an excessive focus on the short-term. In combination with our empirical results, such benchmarking with industry peers may also be used as an effective communication tool towards investors but also towards other important stakeholder groups to invoke trust and commitment (e.g., employees, trade unions). Further, we provide actionable knowledge by pointing out three key organizational dimensions where long-term orientation seems particularly appropriate and, in fact, critical to firm performance. Last but not least, we hope that our empirical results may serve as an encouragement to short-term oriented managers to reorient their behavior and help reassure long-term oriented managers to stick with their overall course. Results show that managers may well benefit from long-term oriented behavior within their own tenure if they act in due time.

\section{Limitations and future research}

Our indicators for short-term and long-term orientation were derived based on amble previous research on family firms which emphasized long-term orientation as a competitive edge of family firms in comparison to non-family firms. Though previous family firm research greatly supports this notion, more recent trends highlight that we should get more cautious about equating family firms with long-term orientation as some family firms become more finance-oriented and earnings driven. A substantial number of family firms today has institutionalized so-called family offices which operate just like investment funds on the basis of fixed performance hurdle rates. Family firms with such an organizational control structure are likely to lose the long-term oriented traits which have been characteristic for family firms in the past. Further, it needs to be noted 
that though our measures of short-term and long-term orientation are well grounded in family firm research and though initial validity tests indicate that they may be suitable secondary proxies, there is greater need to investigate the validity of our measures. In general, the construction of new measures - both secondary and survey measures - for short-term and long-term orientation provides an important and much needed avenue for future research.

\section{References}

Anderson, R. C.; Reeb, D. 2003. Founding family ownership and firm performance: evidence form the S\&P500, Journal of Finance 58(3): 1301-1328. http://dx.doi.org/10.1111/1540-6261.00567

Bearden, W. O.; Money, R. B.; Nevins, J. L. 2006. A measure for long-term orientation: development and validation, Journal of the Academy of Marketing Science 34: 456-467.

http://dx.doi.org/10.1177/0092070306286706

Bergh, D. 1995. Size and relatedness of units sold: an agency theory and resource-based perspective, Strategic Management Journal 16: 221-239. http://dx.doi.org/10.1002/smj.4250160306

Bushee, B. J. 1998. The influence of institutional investors on myopic R\&D investment behavior, The Accounting Review 73(3): 305-333.

Campbell, T. S.; Marino, A. M. 1994. Myopic investment decisions and competitive labor markets, International Economic Review 35: 855-875. http://dx.doi.org/10.2307/2527001

Chalos, P.; Chen, C. 2002. Employee downsizing strategies: market reaction and post announcement financial performance, Journal of Business Finance and Accounting 29(5): 847-870.

http://dx.doi.org/10.1111/1468-5957.00453

Chan, S.; Martin, J. D.; Kensinger, J. W. 1990. Corporate research and development expenditures and share value, Journal of Financial Economics 26: 255-276.

http://dx.doi.org/10.1016/0304-405X(90)90005-K

Cheng, M.; Subramanyam, K. R.; Zhang, Y. 2007. Earnings guidance and managerial myopia, Working paper. University of Southern California.

Dallas, L. 2012. Short-termism, the financial crisis, and corporate governance, Journal of Corporation Law 37: 264-361

David, P.; Hitt, M.; Gimeno, J. 2001. The influence of activism by institutional investors on R\&D, Academy of Management Journal 44(1): 144-157. http://dx.doi.org/10.2307/3069342

Deutsch, Y.; Keil, T.; Laamanen, T. 2007. Decision-making in acquisitions: the effect of outside directors' compensation on acquisition patterns, Journal of Management 33: 30-56.

http://dx.doi.org/10.1177/0149206306296576

Ewert, R.; Wagenhofer, A. 2005. Economic effects of tightening accounting standards to restrict earnings management, The Accounting Review 80: 1101-1124.

http://dx.doi.org/10.2308/accr.2005.80.4.1101

Graham, J.; Harvey, C. R.; Rajgopal, S. 2005. The economic implications of corporate financial reporting, Journal of Accounting and Economics 40(1): 3-73.

http://dx.doi.org/10.1016/j.jacceco.2005.01.002

Graves, S. 1988. Institutional ownership and corporate R\&D in the computer industry, Academy of Management Journal 31(2): 417-428. http://dx.doi.org/10.2307/256557

Greene, W. H. 2008. Econometric Analysis. $6^{\text {th }}$ ed. Upper Saddle River, NJ: Prentice Hall.

Hansen, G. S.; Hill, C. 1991. Are institutional investors myopic? A time-series study of four technology-driven industries, Strategic Management Journal 12(1): 1-16.

http://dx.doi.org/10.1002/smj.4250120102 
Guzzo, R. A.; Abbott, S. 1990. Family firms as utopian organizations, Family Business Review 3(1): 23-33.

Hausman, J.; Hall, B. H.; Griliches, Z. 1984. Econometric models for count data with an application to the patents-R\&D relationship, Econometrica 52: 909-938. http://dx.doi.org/10.2307/1911191

Hayes, R.; Abernathy, W. 1980. Managing our way to economic decline, Harvard Business Review 58(4): 67-77.

Hill, C. W. L.; Phan, P. 1991. CEO tenure as a determinant of CEO pay, Academy of Management Journal 34(3): 707-717. http://dx.doi.org/10.2307/256413

Hirshleifer, D.; Thakor, A. V. 1992. Managerial reputation, project choice and debt, Review of Financial Studies 5(3): 437-470. http://dx.doi.org/10.1093/rfs/5.3.437

Hofstede, G.; Hofstede, J. G. 2003. Cultures and Organizations - Software of the Mind: Intercultural Cooperation and its Importance for Survival. McGraw Hill.

Hoskisson, R.; Johnson, R. A. 1992. Corporate restructuring and strategic change: the effect on diversification strategy and R\&D intensity, Strategic Management Journal 13(8): 625-634.

http://dx.doi.org/10.1002/smj.4250130805

Jacobson, R.; Aaker, D. 1993. Myopic management behavior with efficient, but imperfect, financial markets: a comparison of information asymmetries in the US and Japan, Journal of Accounting and Economics 16: 383-405. http://dx.doi.org/10.1016/0165-4101(93)90033-C

James, H. S. 1999. Owner as manager, extended horizons and the family firm, International Journal of Economics and Business 6(1): 41-55. http://dx.doi.org/10.1080/13571519984304

Jarrell, G.; Lehn, K.; Marr, K. 1985. Institutional Ownership, Tender Offers and Long-term Investments. Washington, DC: Office of the Chief Economist, Securities and Exchange Commission.

Kets de Vries, M. F. R. 1993. The dynamics of family controlled firms: the good and the bad news, Organizational Dynamics 21(3): 59-71. http://dx.doi.org/10.1016/0090-2616(93)90071-8 Kennedy, P. 1998. A Guide to Econometrics. $4^{\text {th }}$ ed. Massachusetts: Blackwell Publishers.

Laamanen, T.; Keil, T. 2008. Performance of serial acquirers: an acquisition program perspective, Strategic Management Journal 29(6): 663-672. http://dx.doi.org/10.1002/smj.670

Laverty, K. J. 1993. How valid are R\&D measures in empirical tests of "Short-termism"?, Academy of Management Best Paper Proceedings 53: 27-31.

Laverty, K. J. 1996. Economic "Short-termism": the debate, the unresolved issues, and the implications for management practice and research, Academy of Management Journal 21(3): 825-860.

Le Breton-Miller, I.; Miller, D. 2006. Why do some family businesses outcompete? Governance, long-term orientation, and sustainable capability, Entrepreneurship Theory and Practice 30(6): 731-746. http://dx.doi.org/10.1111/j.1540-6520.2006.00147.x

Lee, D. Y.; Dawes, P. L. 2005. Guanxi, trust, and long-term orientation in Chinese business markets, Journal of International Marketing 13(2): 28-56. http://dx.doi.org/10.1509/jimk.13.2.28.64860

Lucier, C.; Kocourek, P.; Habbel, R. 2006. CEO succession - the crest of the wave, Strategy+Business 43: 1-14.

Marginson, D.; Mcaulay, L. 2008. Exploring the debate on short-termism: a theoretical and empirical analysis, Strategic Management Journal 29(3): 273-292.

http://dx.doi.org/10.1002/smj.657

Miller, D.; Le Breton-Miller, I. 2003. Challenge and advantage in family business, Strategic Organization 1(1): 127-134.

Miller, D.; Breton-Miller, L. 2005. Managing for the Long-run - Lessons in Competitive Advantage from Great Family Businesses. Boston, MA: Harvard Business School Press.

http://dx.doi.org/10.1002/smj.245 
Miller, K. 2002. Knowledge inventories and managerial myopia, Strategic Management Journal 23: 689-706.

Narayanan, M. 1985. Managerial incentives for short term results, Journal of Finance 40: 14691484. http://dx.doi.org/10.1111/j.1540-6261.1985.tb02395.x

Papadakis, V. M. 1998. Strategic investment decision processes and organizational performance: an empirical examination, British Journal of Management 9(2): 115-132.

http://dx.doi.org/10.1111/1467-8551.00078

Porter, M. E. 1992. Capital choices: the causes and cures of business myopia, Research Report to the U.S. Government's Council on Competitiveness. Washington D.C.

Ryu, S.; Kabadayi, S.; Chung, C. 2007. The relationship between unilateral and bilateral control mechanisms: the contextual effect of long-term orientation, Journal of Business Research 60: 681-689. http://dx.doi.org/10.1016/j.jbusres.2007.01.015

Sanders, G. 2001. Behavioral responses of CEOs to stock ownership and stock option pay, Academy of Management Journal 44(3): 477-492. http://dx.doi.org/10.2307/3069365

Sappideen, R. 2011. Focusing on corporate short-termism, Singapore Journal of Legal Studies 20: $412-431$.

Stein, J. 1988. Takeover threats and managerial myopia, Journal of Political Economy 96: 61-80. http://dx.doi.org/10.1086/261524

Stein, J. 1989. Efficient capital markets, inefficient firms: a model of myopic corporate behavior, Quarterly Journal of Economics 104: 655-669. http://dx.doi.org/10.2307/2937861

Taylor, G. K.; Xu, Z. R. 2010: Consequences of real earnings management on subsequent operating performance, Research in Accounting Regulation 22: 128-132.

Walters, B.; Kroll, M.; Wright, P. 2007. CEO tenure, board of directors, and acquisition performance, Journal of Business Research 60: 331-338. http://dx.doi.org/10.1016/j.jbusres.2006.12.001

Wooldridge, J. M. 2001. Econometric Analysis of Cross-section and Panel Data. Cambridge, MA: MIT Press.

Woolridge, J. R. 1988. Competitive decline and corporate restructuring: is a myopic stock-market to blame?, Journal of Applied Corporate Finance 1: 26-36.

http://dx.doi.org/10.1111/j.1745-6622.1988.tb00155.x

Woolridge, J. R.; Snow, C. C. 1990. Stock market reaction to strategic investment decisions, Strategic Management Journal 11: 353-363. http://dx.doi.org/10.1002/smj.4250110503

Zahra, S. 1996. Governance ownership, and corporate entrepreneurship: the moderating impact of industry technological opportunities, Academy of Management Journal 39(6): 1713-1735. http://dx.doi.org/10.2307/257076

Zhao, Y.; Chen, K.; Zhang, Y.; Davis, M. 2012. Takeover protection and managerial myopia: evidence from real earnings management, Journal of Accounting and Public Policy 31(1): 109-135. http://dx.doi.org/10.1016/j.jaccpubpol.2011.08.004

Matthias F. BRAUER is Associate Professor of strategy at the University of St. Gallen. He received his doctorate in management from the University of St. Gallen. His research interests are in the areas of corporate strategy and governance. He has published in Academy of Management Journal, Strategic Organization, Journal of Management, Corporate Governance: An International Review, British Journal of Management and Journal of World Business, among others. 